慶應義塾大学学術情報リポジトリ

Keio Associated Repository of Academic resouces

\begin{tabular}{|c|c|}
\hline Title & Antihypertensive effect of synthetic tetrandrine derivatives in SHR rats \\
\hline \multicolumn{2}{|l|}{ Sub Title } \\
\hline Author & $\begin{array}{l}\text { 川島, 紘一郎(Kawashima, Koichiro) } \\
\text { 早川, 晃正(Hayakawa, Terumasa) } \\
\text { 大畑，尚代(Ohata, Hisayo) } \\
\text { 藤本，和子(Fujimoto, Kazuko) } \\
\text { 鈴木，岳之(Suzuki, Takeshi) } \\
\text { 荻野，達則(Ogino, Tatsunori) } \\
\text { 陳，政雄(Chen, Zhengxiong) }\end{array}$ \\
\hline Publisher & 共立薬科大学 \\
\hline Publication year & 1991 \\
\hline Jtitle & $\begin{array}{l}\text { 共立薬科大学研究年報 (The annual report of the Kyoritsu College of } \\
\text { Pharmacy). No.36 (1991.) , p.47-47 }\end{array}$ \\
\hline \multicolumn{2}{|r|}{ (2) } \\
\hline \multicolumn{2}{|l|}{ Abstract } \\
\hline Notes & 抄録 \\
\hline Genre & Technical Report \\
\hline URL & $\begin{array}{l}\text { https://koara.lib.keio.ac.jp/xoonips/modules/xoonips/detail.php?koara_id=AN00062898-0000003 } \\
\text { 6-0047 }\end{array}$ \\
\hline
\end{tabular}

慶應義塾大学学術情報リポジトリ(KOARA)に掲載されているコンテンツの著作権は、それぞれの著作者、学会または出版社/発行者に帰属し、その権利は著作権法によって 保護されています。引用にあたっては、著作権法を遵守してご利用ください。

The copyrights of content available on the KeiO Associated Repository of Academic resources (KOARA) belong to the respective authors, academic societies, or publishers/issuers, and these rights are protected by the Japanese Copyright Act. When quoting the content, please follow the Japanese copyright act. 


\section{Antihypertensive Effect of Synthetic Tetrandrine Derivatives in SHR Rats*}

Koichiro Kawashima, Terumasa Hayakawa, Hisaya Oohata, Kazuko Fujmoto, Takeshi Suzuki, Tatsunori OgIno** and Zhengxiong CHEN (Masao CHIN)**

川島紘一郎, 早川晃正, 大畑尚代, 藤本和子, 鈴木岳之, 荻野達則 ${ }^{* *}$, 陳 政雄 ${ }^{* *}$,

1. Effects of oral administration of synthetic tetrandrine (TD) derivatives $(20 \mathrm{mg} / \mathrm{kg}$ per day) for 9 weeks on blood pressure, heart rate, plasma renin concentration (PRC) and vascular reactivities to pressor substances were studied in spontaneously hypertensive (SHR) rats.

2. 7-O-Ethyl fangchinolin (7-O-EFC) and 7-O-isopropyl fangchinolin (7-O-IFC) produced a significant and sustained reduction in blood pressure from the first week of administration. 7-O-EFC reduced heart rate when determined under restraint conditions, but not under unanesthetized, freely moving conditions.

3. TD derivatives produced no effect on PRC.

4. Pressor response to phenylephrine was reduced significantly whereas the response to angiotensin II was enhanced after prolonged administration of 7-O-EFC and 7O-IFC.

5. These results demonstrate that TD derivatives are potential antihypertensive drugs, and that attenuation of the pressor response to phenylephrine may contribute at least in part to its antihypertensive effect.

* 本報告はGen. Pharmac. Vol. 22, No. 1, pp. 165-168（1991）に発表.

** 津村研究所 